\title{
CZY CHORYCH NA OLBRZYMIOKOMÓRKOWE ZAPALENIE TĘTNIC BADAĆ W KIERUNKU ROZWOJU TĘTNIAKÓW AORTY?
}

\author{
SHOULD PATIENTS WITH GIANT CELL ARTERITIS BE TESTED \\ FOR AORTIC ANEURYSMS?
}

\author{
Klinika Reumatologii i Chorób Wewnętrznych Pomorskiego Uniwersytetu Medycznego w Szczecinie \\ ul. Unii Lubelskiej 1, 71-252 Szczecin \\ Kierownik: prof. dr hab. n. med. Marek Brzosko
}

\begin{abstract}
Summary
Aortitis is one of the manifestations of giant cell arteritis (GCA) and is included in its definition. There is a significantly increased risk of aortic aneurysm formation in GCA patients. In some GCA patients aortic aneurysm dissection is diagnosed only in autopsy. Monitoring of these patients, especially in long lasting disease, requires a doctor's awareness of the possibility of aneurysm formation and aortic aneurysm dissection. Based on the available reports it cannot be confirmed whether intensification of aortitis treatment in GCA prevents the development of aneurysms.

This article presents an overview of the available literature and our own experience on a rational diagnosis of inflammation and aneurysms of the aorta in GCA, as well as the prospects for its prevention.
\end{abstract}

K e y words: giant cell arteritis - aortic aneurysm computed tomography.

\section{Streszczenie}

Zapalenie aorty to jedna z możliwych lokalizacji olbrzymiokomórkowego zapalenia tętnic (GCA). U chorych na GCA istotnie częściej niż w populacji ogólnej dochodzi do rozwoju tętniaków aorty. Część rozpoznań tętniaków rozwarstwiających aorty w przebiegu GCA stawiane jest jednak dopiero pośmiertnie. Monitorowanie tych chorych, szczególnie przy długim czasem trwania choroby, wymaga od lekarza świadomości możliwości wystąpienia tętniaków i tętniaków rozwarstwiających aorty. Na podstawie dostępnych doniesień nie można potwierdzić czy intensyfikacja leczenia zapalenia aorty w GCA zapobiega rozwojowi jej tętniaków.

W pracy przedstawiono przegląd dostępnego piśmiennictwa oraz doświadczenia własne na temat racjonalnej diagnostyki zapalenia i tętniaków aorty w GCA, a także perspektyw ich prewencji.

H a s $\nmid$ a: olbrzymiokomórkowe zapalenie tętnic - tętniak aorty - tomografia komputerowa.

Olbrzymiokomórkowe zapalenie tętnic (giant cell arteritis - GCA) to $z$ definicji zapalenie aorty i jej głównych gałęzi, zwłaszcza zewnątrzczaszkowych gałęzi tętnicy szyjnej [1]. Dawniej używana nazwa „zapalenie tętnicy skroniowej" odwołuje się tylko do jednej, chociaż najczęstszej manifestacji choroby. Obecnie coraz więcej uwagi poświęca się zapaleniu tętnic innych niż skroniowa, czyli aorty i dużych gałęzi odchodzących od jej łuku. U chorych na GCA istotnie częściej niż w populacji ogólnej dochodzi do rozwoju tętniaków aorty [2, 3]. Prieto-González $i$ wsp. [4] przedstawili niedawno interesującą hipotezę tłumaczącą powstawanie tętniaków i tętniaków rozwarstwiających aorty w GCA. Autorzy sugerują, że przyczyna może być mechaniczna. W przebiegu GCA dochodzi do zwiększonej sztywności zapalnie zmienionej ściany aorty, często na całej jej długości. Może to powodować wzrost ciśnienia w aorcie, maksymalnie nasilony w jej części wstępującej (ryc. 1). To z kolei może predysponować do uszkodzenia ściany, a następnie poszerzenia średnicy całego naczynia i powstawania tętniaków. 


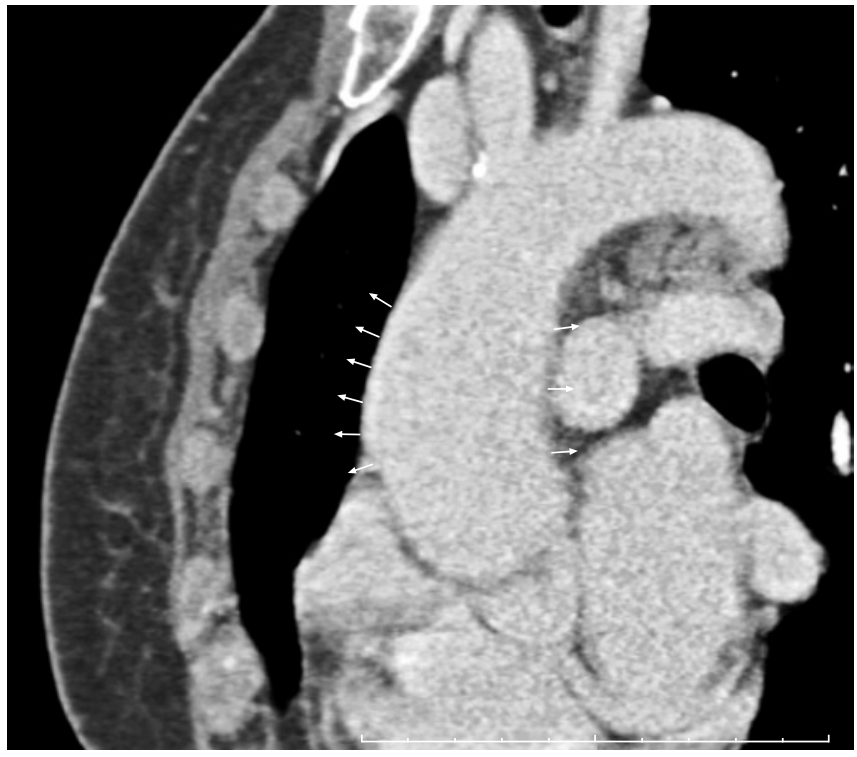

Ryc. 1. Badanie tomografii komputerowej z kontrastem aorty piersiowej. Dyskretne cechy jednolitego pogrubienia ściany aorty widoczne jako obecny zarys ściany pomiędzy wypełnionym kontrastem światłem naczynia a płucami to wyraz zapalenia aorty. Zwiększona sztywność zapalnie zmienionej ściany aorty powoduje wzrost ciśnienia w części wstępującej aorty (strzałki), co prowadzi do jej poszerzenie. Materiał własny wg hipotezy Prieto-González i wsp. [4]

Dla GCA typowe są powikłania niedokrwienne, takie jak ślepota, które są wynikiem zamknięcia światła tętnic na tle ich zapalenia. Do tej pory nie opisano zamknięcia światła tętnicy głównej. Zapalenie aorty jest jednak uważane za czynnik ryzyka rozwoju tętniaków i tętniaków rozwarstwiających. Może być skąpoobjawowe, aż do czasu pojawienia się jego powikłań. Obserwacje epidemiologiczne na temat częstości jego występowania mogą być więc niedoszacowane. Zasady postępowania w przypadku stwierdzenia zapalenia aorty nie zostały dobrze umotywowane wynikami badań, chociaż paradoksalnie wg klasyfikacji z Chapel Hill to właśnie zapalenie aorty defininiuje GCA [1]. Nie można jednoznacznie określić, czy intensyfikacja leczenia zapalenia aorty w GCA zapobiega rozwojowi jej tętniaków.

Od wielu lat powszechnie uważano, że częstość wystąpienia tętniaków aorty piersiowej w GCA jest 17 razy większa niż populacji ogólnej, a brzusznej 2,4 razy większa. Dane te pochodzą z badania Evansa $i$ wsp. z 1995 r. [5]. Wykorzystano w nim rzadko stosowaną obecnie metodę angiografii klasycznej, a porównań dokonano bez grupy kontrolnej, jedynie w oparciu o populacyjne dane epidemiologiczne. Niedawno przeprowadzone badania przyniosły wątpliwości co do istotności problemu wystąpienia tętniaków aorty w GCA. Robson i wsp. [6] zbadali to ryzyko, analizując rozpoznania pochodzące $\mathrm{z}$ rejestrów lekarzy rodzinnych w Wielkiej Brytanii. Porównano rozpoznania u 6999 chorych na GCA i 41994 pacjentów bez tej choroby. Na tej podstawie wykazano, że ryzyko wystąpienia tętniaka aorty w GCA jest zwiększone zaledwie 2-krotnie. Autorzy wnioskowali, że na podstawie aktualnego stanu wiedzy badania przesiewowe $\mathrm{w}$ tym kierunku nie powinny być rutynowo zalecane, chociaż podkreślili, że GCA jest jednym z czynników ryzyka rozwoju tętniaków aorty. Ponieważ badanie miało obserwacyjny charakter, nie wiadomo czy wykazało faktycznie mniejszą częstość występowania tętniaków aorty u chorych na GCA, czy tylko potwierdziło fakt, że są skąpoobjawowe i nie wykonuje się badań w tym kierunku. Nadal część rozpoznań tętniaków rozwarstwiających aorty w przebiegu GCA stawiane jest pośmiertnie i jest podawana jako przyczyna zgonu. Śmiertelność u chorych na GCA z tętnikami aorty jest większa niż bez tego powikłania (standaryzowany współczynnik umieralności 2,$63 ; 95 \%$ CI 1,78 to 3,73 ) [7].

Obecnie można zastanowić się nad tym, czy chorych na GCA należy badać w kierunku obecności cech zapalenia i tętniaków aorty. Ponieważ znaczenie rokownicze zapalenia aorty nie jest jednoznacznie określone, dlatego opinie na temat konieczności i zakresu badań w tym kierunku są bardzo różne. Problem polega na dostosowaniu zakresu badań radiologicznych do istotności zagrożenia dla zdrowia i życia chorego. W diagnostyce typowego dla GCA zapalenia i tętniaka aorty piersiowej największą rolą odgrywają badania związane z istotną ekspozycją na promieniowanie rentgenowskie - tomografia komputerowa TK lub kosztowne - tomografia rezonansu magnetycznego i pozytonowa tomografia emisyjna - PET. Przeprowadzenie w najbliższej przyszłości randomizowanych, wieloletnich badań nad przydatnością takich procedur jest mało realne. Być może zastosowanie w tym wskazaniu znajdzie badanie ultrasonograficzne (USG), które coraz częściej stosowane jest w GCA. Brak badań potwierdzających przydatność tej metody w monitorowaniu cech zapalenia aorty nie pozwala jednak na jej zalecenie w rutynowej ocenie chorych na GCA. Monitorowanie chorych z długim czasem trwania choroby wymaga od lekarza świadomości możliwości wystąpienia tętniaków i tętniaków rozwarstwiających aorty. Częstość ich występowania zwiększa się po 5 latach od diagnozy. Szczególnej uwagi wymaga ból w klatce piersiowej u chorego na GCA, gdyż może on mieć przyczynę pozasercową, a także objawy niedokrwienia narządów i kończyn związane z zamknięciem tętnic odchodzących od aorty przy jej rozwarstwieniu, a także objawy uciskowe związane z uciskiem tętniaka na okoliczne narządy [7]. Obecność tętniaka aorty piersiowej można niekiedy rozpoznać w standardowym zdjęciu radiologicznym klatki piersiowej jako poszerzenie łuku aorty.

Mackie $i$ wsp. [8] podjęli się metaanalizy i przeglądu piśmiennictwa, aby odpowiedzieć na pytanie, czy chorzy na GCA wymagają skriningowej TK. Okazało się, że trzeba wykonać TK u 5-10 chorych na GCA, aby rozpoznać jedno poszerzenie lub tętniaka aorty piersiowej. Tylko część chorych z tym rozpoznaniem wymaga operacji naczyniowej. Zalecenia co do leczenia operacyjnego tętniaków aorty w przebiegu GCA i populacji ogólnej aktualnie nie różnią się. Niewiele wnosi stwierdzenie obecności tętniaka niewymagającego jeszcze operacji, ponieważ nie wiadomo, czy leczenie wpływa na zahamowanie rozwoju tętniaków aorty w GCA. Podstawą terapii zaostrzeń GCA jest zwiększanie 
dawek glikokortykosteroidów (GKS). Stwierdzenie obecności tętniaka aorty nie musi być jednak wyrazem aktualnej aktywności choroby, a jedynie jej przebytego w przeszłości zapalenia. Jedynym badaniem umożliwiającym ocenę aktywności zapalenia aorty, a nie tylko zmiany jej struktury, jest PET. Istnieją dowody na to, że leczenie GKS obniża sztywność ściany tętnic, może więc potencjalnie zmniejszyć ciśnienie w aorcie [9]. Glikokortykosteroidy w małych dawkach hamują odczyn zapalny (sprawdzają się w leczeniu objawów polimialgii reumatycznej), nie leczą jednak zapalenia tętnic. Należy jednak unikać długotrwałego stosowania GKS, ponieważ podwyższa ono ryzyko sercowo-naczyniowe w chorobach reumatycznych, w tym związane z rozwojem tętniaków aorty [10]. Racjonalnym rozwiązaniem u chorych na GCA z czynnikami ryzyka rozwoju tętniaków aorty (np. z poszerzeniem jej światła) i wymagających przewlekłego leczenia wydaje się być stosowanie leków umożliwiających redukcję dawki GKS. Należą do nich leki immunosupresyjne - najczęściej w GCA zalecany jest metotreksat oraz leki biologiczne, wśród których aktualnie badany jest tocilizumab [11]. Na pewno chorzy z zapaleniem lub tętniakiem aorty mogą odnieść korzyści z intensywnej kontroli nadciśnienia tętniczego i czynników ryzyka chorób sercowo-naczyniowych.

Propozycją kwalifikacji chorego do badania naczyniowego aorty w oparciu o doświadczenia własne i dostępne piśmiennictwo mogą być:

1. Objawy kliniczne niedokrwienia kończyn w GCA spowodowanego zwężeniem tętnic odchodzących od aorty.

2. Stwierdzenie w badaniu USG pogrubienia ściany tętnic podobojczykowych, pachowych, szyjnych lub udowych bez typowych dla miażdżycy kalcyfikacji. Zapalenie aorty często wiąże się z zapaleniem odchodzących od niej tętnic.

3. Objawy kliniczne tętniaka rozwarstwiającego aorty.

4. Stwierdzenie w badaniu USG serca poszerzenia światła lub pogrubienia ściany aorty wstępującej lub poszerzenie cienia aorty sugerujące obecność tętniaka w standardowym badaniu radiologicznym klatki piersiowej.

5. Oporna na typowe leczenie postać GCA, ponieważ może to wynikać z aktywnych zmian zapalnych aorty.

6. Oporna na typowe leczenie postać polimialgii reumatycznej, ponieważ może to sugerować współistnienie GCA z zapaleniem aorty i jej gałęzi.

Chorzy na GCA mają podwyższone ryzyko rozwoju tętniaków aorty, których częstość występowania rośnie z czasem trwania choroby. Monitorowanie tych chorych wymaga od lekarza świadomości możliwości wystąpienia tętniaków i tętniaków rozwarstwiających aorty w celu szybkiego kierowania chorych na leczenie chirurgiczne. Profilaktyka wystąpienia i progresji tętniaków aorty nie jest poparta dowodami naukowymi. Racjonalnym rozwiązaniem jest:

1. Stosowanie na początku choroby odpowiednio wysokich dawek GKS, ponieważ zbyt małe dawki nie leczą zapalenia tętnic.

2. Unikanie przedłużonego stosowania GKS po osiągnięciu remisji choroby, ponieważ GKS mają działanie miażdżycogenne.

3. Rozważenie włączenia leków immunosupresyjnych, a w przyszłości być może również biologicznych, z intencją zmniejszenia dawki GKS.

\section{Piśmiennictwo}

1. Jennette J.C., Falk R.J., Bacon P.A., Basu N., Cid M.C., Ferrario F. et al.: 2012 revised International Chapel Hill Consensus Conference Nomenclature of Vasculitides. Arthritis Rheum. 2013, 65, 1-11.

2. Milchert M., Brzosko M.: Olbrzymiokomórkowe zapalenie tętnic i polimialgia reumatyczna. In: Reumatologia 2010/2011 nowe trendy. Ed: P. Wiland. Wyd. Termedia, Poznań 2011.

3. Milchert M., Brzosko M.: Olbrzymiokomórkowe zapalenie tętnic. In: Reumatologia kliniczna. Ed. M. Brzosko. Wyd. Pom. Uniw. Med. w Szczecinie, Szczecin 2010, 211-214.

4. Prieto-González S., Arguis P., García-Martínez A., Espígol-Frigolé G., Tavera-Bahillo I., Butjosa M. et al.: Large vessel involvement in biopsy-proven giant cell arteritis: prospective study in 40 newly diagnosed patients using CT angiography. Ann Rheum Dis. 2012, 71, 1170-1176.

5. Evans J.M., O'Fallon W.M., Hunder G.G.: Increased incidence of aortic aneurysm and dissection in giant cell (temporal) arteritis. A population-based study. Ann Intern Med. 1995, 122, 502-507.

6. Robson J.C., Kiran A., Maskell J., Hutchings A., Arden N., Dasgupta B. et al.: The relative risk of aortic aneurysm in patients with giant cell arteritis compared with the general population of the UK. Ann Rheum Dis. 2015, 74 (1), 129-135.

7. Kermani T.A., Warrington K.J., Crowson C.S., Ytterberg S.R., Hun$\operatorname{der}$ G.G., Gabriel S.E. et al.: Large-vessel involvement in giant cell arteritis: a population-based cohort study of the incidence-trends and prognosis. Ann Rheum Dis. 2013, 72, 1989-1994.

8. Mackie S.L., Hensor E.M., Morgan A.W., Pease C.T.: Should I send my patient with previous giant cell arteritis for imaging of the thoracic aorta? A systematic literature review and meta-analysis. Ann Rheum Dis. 2014, 73, 143-148.

9. Schillaci G., Bartoloni E., Pucci G., Pirro M., Settimi L., Alunno A. et al.: Aortic stiffness is increased in polymyalgia rheumatica and improves after steroid treatment. Ann Rheum Dis. 2012, 71, 1151-1156.

10. Ohara N., Miyata T., Kurata A., Oshiro H., Sato O., Shigematsu H.: Ten years' experience of aortic aneurysm associated with systemic lupus erythematosus. Eur J Vasc Endovasc Surg. 2000, 19, 288-293.

11. Sciascia S., Rossi D., Roccatello D.: Interleukin 6 blockade as steroid-sparing treatment for 2 patients with giant cell arteritis. J Rheumatol. 2011, 38, 2080-2081. 